\title{
Professor Koeber Watsuji Tetsurō
}

\section{Kyle Michael James Shuttleworth ${ }^{1}$ (D) S Sayaka Shuttleworth ${ }^{1}$}

Received: 21 October 2020 / Revised: 5 February 2021 / Accepted: 2 March 2021 /

Published online: 1 May 2021

(C) The Author(s), under exclusive licence to Springer Nature Switzerland AG 2021

\begin{abstract}
In this translation, Watsuji Tetsurō provides an overview of the life and work of Raphael von Koeber who introduced and taught philosophy at Tokyo Imperial University to some of the most eminent Japanese intellectuals of that period. Watsuji focuses on the character of Koeber, rather than his intellectual achievements, as having an incomparably profound effect upon his students. In this regard, by discussing his sphere of influence, Watsuji simultaneously provides us with an insight into the shared intellectual heritage of many of Japan's foremost philosophers, novelists, and academics, and subsequently raises awareness of the importance of Koeber himself.
\end{abstract}

Keywords Natsume Sōseki · Nishida Kitarō · Raphael von Koeber · Uozumi Kageo • Watsuji Tetsurō

\section{Translator's Commentary}

The subject of this essay, Raphael von Koeber, is a relatively-unknown German-born philosopher who profoundly influenced some of Japan's most eminent thinkers of the twentieth century. The simple, honest title of Watsuji's essay, "Koeber Sensei" captures the essence of Koeber well - he was not the greatest philosopher, but he was highly influential and respected as an educator. This is made explicit by Natsume Sōseki, who exclaims "If you ask the students of the Faculty of Letters in Tokyo Imperial University who has the best personality among all the professors, ninety percent will answer 'Koeber' rather than nominating any one of many Japanese professors. Respected so much, he is interested in Japanese students and has continued to teach philosophy for eighteen years. He does not leave Japan because of his love for the students" (1994: 465-466). Koeber epitomised the stereotype of an academic: lofty, astute, and thoughtful. As Gino Piovesana aptly puts it, "He was an artistic type of sage-philosopher, who

Kyle Michael James Shuttleworth

kyles@ rikkyo.ac.jp

1 Rikkyo University, Tokyo, Japan 
incarnated the almost mystical ideal of a tutor" (2013: 50). For these reasons, Koeber commanded a cult-like following, and his unworldliness attracted the devotion of students who hung off his every word. Aside from Watsuji's own memoir, many of Koeber's well-renowned students also committed their own memories of Koeber to paper, including Natsume Sōseki, Nishida Kitarō, Hatano Seiichi, Abe Jirō, and Miki Kiyoshi.

In terms of courses, Koeber taught aesthetics and classics at Tokyo Imperial University, though he is perhaps best remembered for the latter of these. According to Hiroshi Nara, "aside from Sakaguchi [Noboru]'s book on Hellenism, the most influential person in training a generation of scholars versed in Classicism was Raphael von Koeber" (2018: 191). And whilst Watsuji notes that Koeber defined his own philosophy as somewhere in-between Stoicism and Epicureanism, within his lectures Koeber placed a heavy emphasis on the dialogues of Plato. Indeed, he is reputed to have said, "My desire for metaphysics is, after all, sufficiently satisfied by ancient Greeks. Philosophy after them is, frankly, no more than a kind of luxury - inasmuch as we already have Plato with us" (1923: 3). As a classically trained scholar, Koeber also believed that Greek and Latin were not only essential to the study of philosophy, but also the understanding of European culture. Insisting that his students ought to learn these, he even offered private lessons to selected students. Indeed, this neglect of languages was central to Koeber's criticism of the Japanese intellectual tradition. Namely, he condemned the attitude of total adoption of European culture on the grounds that Japanese intellectuals metaphorically plucked the flower of learning without removing the root.

Similar criticisms have been made by other European intellectuals who spent a considerable amount of time in Japan. Basil Hall Chamberlain, for example, exclaimed "The young professors who now are founding a new school of thought known under the name of 'culturalism' do little but repeat the ideas thought out by European philosophers, just as their fathers repeated Chinese ideas" (2007: 399). Moreover, Karl Löwith likewise argued that "Japanese philosophers are like people living in a twostory house, filling shelves on the second floor with volumes and volumes of treatises on philosophers from the Greeks to the present day, while on the first floor they go on thinking and feeling like Japanese as usual. There is no staircase in sight that connects to the things that came from abroad" (1998: 228). However, while Chamberlin and Löwith simply criticise the Japanese intellectual tradition, Koeber can be seen to offer a resolution. That is, by emphasising that his students learn Greek and Latin, and by actually teaching classical languages, Koeber provided the means for upcoming Japanese intellectuals to properly understand western philosophy and European culture, and thereby move the root of the flower to Japan.

Although Watsuji's memoir focuses on his experience of Koeber as an educator in philosophy at Tokyo Imperial University, Koeber was also a well-established musician. Indeed, Koeber composed his own songs which were preserved as manuscripts, and bequeathed to Tachibana Itoshige, to whom he had taught piano to at a music school in Ueno. Tachibana took great care to preserve Koeber's manuscripts, and according to an anecdote, "When a strong earthquake hit Kanto the following year after Koeber's death, [Tachibana] tried to save Koeber's musical heritage putting the preservation of these before that of his own possessions" (1923: 20). Itoshige not only preserved Koeber's music in written form, but also released it on mimeograph in 1927, distributing copies to friends and acquaintances. One of the people to whom this collection of songs on 
mimeograph was given to was Tachibana's piano student Iwanami Yuri. A copy was later obtained by Komatsu Misako, Iwanami Yuri's niece, who submitted the music to Ongakunotomosha where it was released in 1992, and again in 1998 on CD in memory of the 150th anniversary of Koeber's birth. According to Kubo Masaru, Koeber was fond of the poetry of Eichendorff, which he took to be musical, and composed one of his songs to Eichendorff's poem "From The Shore".

As for Watsuji's memoir itself, it is not simply a personal account written from his own perspective, but a well-balanced depiction, which, as one would expect from a scholar, draws upon a variety of sources to substantiate his claims. In terms of Watsuji scholarship, this is the only direct source of Watsuji's relation to Koeber. ${ }^{1}$ Even though Watsuji composed an autobiography, it only goes as far as life at Tokyo First Higher School - which was a prep school for Tokyo Imperial University - as Watsuji passed away before it was completed. The only other mention of Koeber comes from Watsuji's wife's biography, which draws upon letters which Watsuji composed to her during his university days. As presented in the translation below, Koeber possessed expertise on Schopenhauer - he obtained his degree based on a thesis on Schopenhauer titled "The Study on Human Freedom" (1881), wrote An Explanation of the Discourse of Schopenhauer, the Schopenhauer chapter for Albert Schwegler's History of Philosophy, and published a monograph titled The Philosophy of Schopenhauer (1887). In Watsuji Teru's biography we learn that whilst a final year student at Tokyo Imperial University, Watsuji wrote his own dissertation in English on "Schopenhauer's Pessimism and Salvation Theory" so that it could be submitted to Koeber sensei (1962: 29).

Testament to Koeber's importance is also provided by several of Japan's most prominent thinkers of the twentieth century. In his memoir, Natsume Sōseki emphasizes Koeber's devotion to his students: "I could not help wondering how long he intended to remain in Japan. It had become clear that were it not for his students, he would surely have departed this bleak and dismal land long ago" (Marcus 2009: 165). As one would expect from a novelist, Natsume dramatizes Koeber's unworldliness by portraying him as anachronistic. Perhaps influenced by Koeber's lessons on classical philosophy and emphasis that students should learn Greek and Latin to read philosophy in its original source, Natsume caricatures Koeber as akin to an ancient relic amidst a modern metropolis. As Natsume colourfully conceives, "He is like a Greek statue that has come to life, discarded in some vast junkyard. Amid the hustle and bustle, he moves about ever so quietly. As he walks the pavements, his shoes move silently, no sound of hobnails clattering against stone. Like an ancient Greek wearing sandals of supple leather, he strolls soundlessly as the trolleys rumble by" (Marcus 2009: 164-165). Further evidence of Koeber's influence upon Natsume can also be observed in the novel Kokoro, where it has been inferred that the characters of sensei, the student, and the foreigner in Kamakura, respectively refer to Natsume, Watsuji, and Koeber. (Yuasa 1996: 315).

Japan's most influential philosopher, Nishida Kitarō, the founder of the Kyoto School of thought - which sought to establish "Japanese philosophy" by explaining Buddhist philosophical thought through a Western philosophical framework - was another of Koeber's renowned students who also composed a tribute to his professor. In

\footnotetext{
${ }^{1}$ Although Watsuji composed a memoir on Koeber for the 1923 special edition of Shiso, this was later modified to become the below translation.
} 
Nishida's account, Koeber is presented as a serious academic who pedantically pressed his point about the study of original texts. As Nishida recalls, "On one occasion, I visited Professor Koeber and asked if any of St. Augustine's texts had been translated into modern languages. Professor Koeber replied that there was a French translation, but asked "why do you not study Latin?" I answered that it would be difficult for Japanese students to study Greek and Latin, though he argued that it is thoughtless to try to understand Western philosophy without knowing classical languages, and said so-and-so in the same class as you reads Greek, 'You must read Latin at least'." Rather than superficial learning, Koeber also drilled into his students the importance of specialisation. As Nishida further testifies, "Also once when I said cheekily what sounded like a refutation of Hegel's philosophy, he said "Warum? Warum?" (Why? Why?), and attacked me. And warned me, saying "non multa sed multum" (not many things, but one thing deeply) again and again. Although these words were said to me in particular, I think Professor Koeber thought this about all Japanese students in general" (1923: 32).

In addition to learning about Koeber, we also gain an insight into the life of the highly influential but relatively unknown Uozumi Kageo, who did not live long enough to reach his potential. Uozumi features heavily in Watsuji's autobiography, where he is listed as a great influence, and even helped to determine Watsuji's intellectual trajectory by advising him to enter into the department of philosophy, rather than literature at Tokyo First Higher School (1992: 370). Uozumi was the son of a prefectural politician, and an outspoken critic of practices which he perceived to be oppressive. At Himeiji Middle School, Uozumi attacked the administration of the alumni association and the disorder of public finance, and urged the principal to punish a classmate who conducted a politically-motivated martial arts demonstration at the theatre (1992: 280). At Tokyo First Higher School, he attacked conservative practices such as the compulsory lodging system, which he criticised from the standpoint of individualism (1992: 361). He also wrote several influential essays including a commentary on the infamous suicide of Fujimura Masao, which resonated with the youth at that time, an essay on Naturalism as the idea of self-assertion, and several other pieces which were posthumously assembled and published (1914). However, it is in the essay below that we learn how Uozumi formally introduced Watsuji to Koeber and the cause and date of Uozumi's premature death.

Aside from providing a valuable source for scholars of modern Japanese studies, Watsuji's Professor Koeber also resonates with the modern academic in helping to remind us what it means to be a good teacher. To the extent that he will not be remembered for developing any great philosophical system, or for establishing a fundamental principle - the standard by which great philosophers are often judged "Professor Koeber's life was externally quite poor". However, his merit lies in the influence exercised upon those who encountered him. At a time when universities measure success in terms of research achievement, and prioritise research grants over quality of teaching, it is all too easy to forget our most fundamental duty. Bearing this in mind, Professor Koeber ought to be read, not simply as a memoir, but as an ode to those educators who put their students first. It gives us cause to reflect upon and respect those educators whose priority is to inspire others, rather than to satisfy their own ambitions.

As discussed above, there are several reasons why this essay is important. First and foremost, it is a valuable source of information about Raphael von Koeber himself. 
Koeber was at the centre of learning in Tokyo, and whilst a relatively-unknown scholar outside of Japan, he influenced a generation of Japanese intellectuals and deserves greater exposure for his role in education. This essay also helps us to better understand the intellectual climate of early twentieth century Tokyo. Namely, it provides insight into the education provided at Tokyo Imperial University - not only in terms of what was taught, but how it was taught. In this regard, it is not only beneficial for Watsuji scholars but also for scholars of other major thinkers, such as Natsume Sōseki, and Nishida, Kitarō, by illuminating their education and the shaping of their intellectual development. It is also an important source about lesser known intellectuals such as Uozumi Kageo, who not only influenced Watsuji, but also provided scathing social critiques, though whose life was tragically cut short. And whilst Watsuji's Professor Koeber provides an important source for philosophers, scholars of literature, and intellectual historians, it is also relevant to contemporary scholars, helping us reflect upon the true role of an academic. K.M.J.S.

\section{Professor Koeber ${ }^{2}$}

\section{Professor Koeber}

If Professor Koeber provided a detailed recollection of his life by utilising his vivid power which "seizes the main point" and his intuitive descriptive ability, I think we would have a very beneficial and interesting autobiography. However, Professor Koeber was the sort of person who "did not like talking about personal affairs". Thus, he strongly detested "talk about himself and confession which looks modest at first sight, but which nevertheless expresses extreme vanity and arrogance". When Professor Koeber wrote about his personal affairs, it was only when necessary and to provide the impression which he was trying to convey. According to Kubo Masaru, in order to please Kubo at dinner (because Kubo was delighted to hear his recollections), Professor Koeber often strived to talk about his past. If so, Fukada, who was closely associated with Professor Koeber for twenty years and also spent his daily life with him for five years, would surely have learned a lot from listening. We will soon have an opportunity to hear the details about sensei's life from these people.

Nonetheless, Professor Koeber's life was externally quite poor. Rather, his charm seemed to be in having an unusual spirit of freedom which appeared in his quiet daily life, and his way of moving the spirit of others at every opportunity. However, on this point as well, Fukada and Kubo, who were Professor Koeber's life-long companions, and directly experienced his way of moving one's spirit, are the most certain witnesses. According to Kubo, the spontaneous words which Professor Koeber uttered at every occasion were often meaningful and of great enough interest that Kubo wanted to record them as they were. With regard to such information, the above two people also provide the best source.

For the primary source of this essay, I would like to draw upon the writing of Suzuki Masuo, who spent his youth by Professor Koeber's side from around 1896 to 1903, add

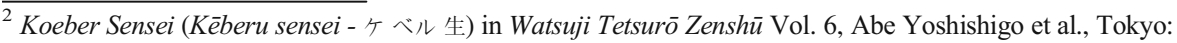
Iwanami Shoten. (Watsuji 1992) pp. 5-39. Originally published in 1948.
} 
Professor Koeber's recollections from his Collection of Literary Sketches, Kubo's memoir about Professor Koeber's final illness, and add another two or three sources to supplement Kubo's simple biography. ${ }^{3}$ I am of course not a suitable candidate to compose Professor Koeber's biography, but it would be fortunate if I could contribute something which will provide the basis for a good biography to be written in the future.

\section{A Biographical Sketch of Dr. Koeber}

- $\quad$ 15th of January 1848, born in Nizhny Novgorod in Russia. His ancestors on his father's side were all born in Saxony and his Russian blood came from his mother's side mixed with Swedish blood. He lost his mother aged one and was raised by his grandmother on his mother's side.

- Learned the piano at the age of six.

- 1867, after leaving the Gymnasium, entered higher music school in Moscow (Conservatory) contrary to his father's wishes, learned from Nikolai Rubinstein (younger brother of Anton), Tchaikovsky, Klindworth, and so on.

- 1872 , graduated from the music school. Was not suited to the life of a musician due to his shyness and thought of becoming a scholar. Then decided to study abroad in Germany and firstly entered Jena University and studied with Haeckel, Fortlage, Otto Pfleiderer, and so on. Listened to the lectures of Eucken.

- Around 1875, he moved to Heidelberg and studied with Kuno Fischer.

- 1881, gained a degree by thesis on Schopenhauer. After that wrote An Explanation of the Discourse of Schopenhauer, the Schopenhauer chapter of the 11th edition of History of Philosophy by Albert Schwegler and so on, and because of that started to associate with Eduard von Hartmann.

- 1884, published Philosophical System of E. von Hartmann.

- Next proceeded to a new appointment in Karlsruhe music school and resigned after a year and moved to Munich. Engaged in writing here.

- 1887, published The Philosophy of Schopenhauer.

- 1893, published History of Philosophy for Revision. In this year (Meiji 26), upon the recommendation of Hartmann, was invited to be a professor of philosophy at Tōkyō Imperial University.

- During the twenty-one years from then until 1914 (Taishō 3), he devoted himself to lectures and the guidance of students without interruption, and left a large influence as the living figure of an unworldly philosopher. His lectures were not only limited to the area of philosophy but general poetics, history and philosophy of Christianity, Goethe's Faust, Dante's Divine Comedy and so on. Furthermore, he formed the custom of translating Greek and Roman classics with selected students. Also, other than the university, he worked as a piano teacher for many years in a music school in Ueno.

- 1914 , just before boarding a ship to return to Germany, the outbreak of the First World War occurred and he lived in a room of the official residence of the Russian

\footnotetext{
${ }^{3}$ [Watsuji's own note] Kubo Masaru Biographical sketch of Dr Koeber. Kubo wrote this a year before Sensei passed away and this gained sensei's revision. I will provide a chronological record here based on it for the reader's benefit.
} 
consul general Arthur Wilhelm, who was a friend in Yokohama and spent the remaining years quietly engaged in the work of writing.

- 1918, published Collection of Literary Sketches.

- 1921, published Sequel Collection of Literary Sketches.

- 14th of June 1923, passed away at a temporary residence in Yokohama. Buried in Zōshigaya cemetery.

Professor Koeber, who lost his mother when he was one year old, was raised by his grandmother on his mother's side. His grandmother was the daughter of Carl Binder, who moved from Reval in the Baltic Coast to Nizhny Novgorod, constructed a German church there, and was influencial as the person in charge of education for the Empress of the Tsar (perhaps Alexander the second). Thus, she was extremely aristocratic, welleducated and highly elegant. An anecdote which gives a glimpse of her personality is discussed in the Collection of Literary Sketches: A teacher who taught ancient history to Professor Koeber when he was a boy publicised his academic independence and the originality of his lectures during the first period; the Grandmother said to her grandson, who was talking proudly of having a teacher of such extensive learning, "Your teacher seems to be an uneducated and vain person, otherwise he would not decide what you yourself should judge in the future.

To boast of your own achievement, especially to boast in front of one's student is stupid and vulgar."

Professor Koeber received a great deal of influence from his grandmother. He even attributed the habit of taking notes whilst reading to his "grandmother who never spent one day without writing and who always encouraged me to imitate this example". Professor Koeber's warm feeling towards servants and his generous refined attitude might reflect this grandmother's influence. His grandmother was very compassionate towards the servants. She seldom changed. Apparently the wet nurse who raised Professor Koeber and her children, namely Professor Koeber's foster siblings, regularly visited into the distant future. In such an atmosphere, he was occasionally taken to his grandmother's holiday home and experienced Russia as depicted by Turgenev.

Professor Koeber, who was fortunate with his grandmother's love did not have such a good memory of his father. His father used to be a professor of medical science and liked hunting very much. As a boy, Professor Koeber recalls "I always felt a kind of hesitation in front of my father, although not to the extent of fear — that decreeing (arrogant smack of authority), impatient, intense nature and scornful smile - I was always somewhat anxious and dispirited in front of my father." The personality of his father described here does not bear the slightest resemblance to Professor Koeber. Rather, we can say that the opposite personality appeared in Professor Koeber.

Professor Koeber "was thought during early childhood and boyhood — especially from his father - to be quite narrow minded and also even somewhat stupid." However, that was probably a consequence of his father's mistaken belief that the thoughts, imagination, and world of sentiment was a kind of disposition at that time. What attracted and entranced Professor Koeber in those days was "not the four gospels, the epistles, book of prophet or psalms. These were the books which I was obligated to read and I was thoroughly pleased when that period ended. No, what deeply moved me and left me entranced were the tales in Homer and Ovid, German national legends, fairy tales, Arabian Nights and other similar kinds of reading materials." When he was about fifteen or sixteen, he became absorbed in books which his father called "poor pieces of 
modern work" which were cheating the eyes, and who was in bad form unless Professor Koeber studied ancient language or more serious lessons. When he obtained Spielhagen's novel Mysterious People for the first time, he read it throughout the night. He recalls being sad and crying when Monte Cristo, which he had begun to read, was taken away. "More than the things in my textbooks, I know of an extreme amount of students who have a tendency to be lazy but understand the novels of Walter Scott, Brewer and Dumas, - I was also one of those students when I was fifteen or sixteen." In the school in Russia, Professor Koeber was disliked by other students as a German or a foreigner. In his sad life, his grandmother's warm heart was his only resting place. So Professor Koeber only went to school occasionally and quit without waiting for graduation.

Professor Koeber entered a music school in Moscow at the age of nineteen. His father was opposed to this. Professor Koeber says "it is matter of fact that my father and Kuno Fischer called my life a sad fate and cursed because of music". Certainly it was the artist within Professor Koeber that prevented him from becoming a modern German scholar (Wissenschaftler). ${ }^{4}$ However, this artist probably became more distant due to his supposed artistic temperament. "Intense passion, generally intense desire, and the pursuit of things that a large number of people find happiness in, were almost never known to me. So I did not have a so-called frenzied youth." — In Moscow, he was associated with famous musicians such as Rubinstein and Tchaikovsky with whom he often spent cheerful evenings drinking alcohol. And with Tchaikovsky and so on, a close friendship, not just the relationship of a teacher and a student, was established. In later years, when Professor Koeber was invited to Japan, he consulted with Tchaikovsky. Among his friends, it was only himself who was opposed to going to Japan. "It cannot be comfortable at all for someone who should be called the incarnation of a pure European and already quite advanced in years to go to the Orient, and would I surely become unhappy from homesickness".

This music student was still an enthusiastic and avid reader, even when surrounded by musicians. It seems that it was around this time when he was strongly attracted to Schopenhauer, the conjurer. Also, at the shopfront of a bookstore where he went to buy Spiridion by George Sand, which was banned from sale in Russia, he heard the name of Hartmann for the first time. The shop assistant whispered in a lower tone as if to disclose a dreadful secret "there seems to be a recent German book that advocates a heretical doctrine much more intense than Spiridion called Unconscious Philosophy by Hartmann" and threw a timid look towards the direction of his employer.

Professor Koeber became a fully qualified musician at the age of twenty-four. However, his shyness prevented him from life as a musician. Then, with his classmate and best friend Davydov, — who was a violin genius, they went to Jena with the intention of becoming natural scientists. As a result, Professor Koeber listened to Haeckel enthusiastically for the first time. Only Davydov accomplished his desire at this time, and is still in good health as the head of the Russian maritime laboratory in Niece, in the South France, but Professor Koeber soon realised that he was unfit for natural science and turned his focus towards philosophy. However, the personality of

\footnotetext{
${ }^{4}$ In the original text, Watsuji often employs English and German terms. When he does so these have been in italicised in this translation. Where necessary, German phrases have been translated into English with the original German following in brackets.
} 
Haeckel left an extremely strong impression upon him. Later, Professor Koeber insisted that Haeckel was not a materialist - which is what Professor Koeber did not like, and wrote about in Ist Haeckel Materialist?, and when he was writing a draft of some short pieces in Yokohama in his final years, he observed laughter as something that shows the internal, true character of humanity and recollected that "the laughter of Haeckel" was what made people's heart delight, what showed kindness, freedom, and frankness, and therefore, what did not make people angry or hurt their heart was how his virtuous, honest, and free personality appeared in the manner and tone of his laughter.

During the three years in Jena, Professor Koeber obtained the foundation of his philosophical grounding. His teachers at that time, whom he recollects with the feelings of gratitude and appreciation, were none other than Eucken and Haeckel, the philosopher Fortlage who was being taught by the so-called "half Kant school", 5 the theologian Otto Pfleiderer who became famous after that, and Fritz Schulze who connected critical philosophy to evolutionary theory. Around this time, especially in his final year, Professor Koeber enthusiastically studied Schopenhauer. The thought of making a thesis on the concept of the intellectual personality of Kant, Shelling, and Schopenhauer occurred at that time.

In Jena, there were performances of plays for two or three weeks before and after Easter. A great majority of the professors did not even miss one night. Professor Koeber eagerly joined them to watch the plays, and recalls that "viewing plays and operas was always the greatest enjoyment for me."

Three years after that, he moved to Heidelberg in order to be study with Kuno Fischer, and for the five or six years after that, he attended the lectures of this "peerless university professor". And at the age of thirty-three, he completed his degree by thesis on Schopenhauer, which was praised by Kuno Fischer.

The reason why Professor Koeber got to know Hartmann was because he summarized Hartmann's philosophy as the conclusion of Schopenhauer's theory in a chapter which he wrote in Schopenhauer's Theory of Enlightenment, published as a separate volume, it was a revision of the above mentioned thesis and a supplement in the 11th edition of Schwegler's History of Philosophy. Hartmann admired it and urged Professor Koeber to expound his own philosophical system. And after he completed the draft in the autumn of 1883, Professor Koeber met Hartmann for the first time.

At this time, other than meeting Hartmann and thanking him, Professor Koeber was thinking of looking for a position in Berlin. As he notes, "I was hoping to become a person who has duties to accomplish, to be able to serve people and be useful for others, and at the same time, I wanted to get a job to be able to become financially independent (because my fortune was scarce)." This was when Professor Koeber was thirty-five years old. But what kind of occupation did he pursue? Eucken advised him to become a university professor, but the shy Professor Koeber did not have the courage. Also, Professor Koeber, who hatred performing in front of the public could not become an occupational musician. Then, the only remaining road was to become a teacher in a music school. This was the main topic when he met Hartmann, whom was kindly concerned and advised him to make a tour of visitation to principals of many

\footnotetext{
${ }^{5}$ By "half Kant school" Watsuji may be referring to Fortlage's position that Kant was only half right and to supplement this with the thought of Fichte.
} 
music schools in Berlin. However, in the end, the passive Professor Koeber, lacking the ability to "strive to pursue" left Berlin without visiting even one principal.

A few months after Professor Koeber returned to Heidelberg, and was appointed to a music school in Karlsruhe. In the lectures there, he was pleased with the history of music and musical aesthetics. Auditing students were women of all ages, but those who especially attended were Miss Marie Heine and his friend Möbius from university (a botanist and the sibling of the medical scientist Möbius who announced the research of literary philosophers). Professor Koeber recalls that it "made my lectures a fun banquet which could never be erased from my memory."

However, displeasure towards the school manager prevented Professor Koeber from staying there for long. After one year, he moved to Munich where Davydov, his friend from Moscow, was located. "I think the happiest time of my life was the ten years that I lived in Munich. I was able to discover everything I needed and had more than enough expectations in this land. - People of close spiritual resemblance, the library which had the most abundant collection of books in Europe where we could freely come and go, splendid works of art, an active music scene, exemplary plays, beautiful calm nature, and a healthy climate. The Catholic atmosphere of this city was also a considerable reason for attracting my heart to Munich." These blissful memories beckoned him to return to Munich in his final years.

The extent of Professor Koeber's acquaintances was quite vast because of his talent for music - to borrow his words, "because nature gave me a little talent and did not grant me the will to say no to an appropriate opportunity". Natural scientists, philosophers, scholars of literature, theatre supervisors — at one point Professor Koeber discussed a play which had great popularity in those days with a theatre supervisor, and said at the end "I can always enjoy plays the most when I leave my critical glasses at home". The novelist Paul Heyse, who was standing nearby, said "be delighted that you can still do that, I wish I could be like that" in a grave and almost sad tone. - I think this one scene is enough to illustrate how Professor Koeber accumulated acquaintances.

His younger friends had previously criticized his way of thinking and tastes as oldfashioned. However, Professor Koeber did not have any interest towards the "new things" or "modern things" which his friends were admiring. He also detested repeating and advocating what had already been sufficiently espoused by authors in an extremely old era. That is to say, that Professor Koeber had already started to become stuck in his way from this time.

What brought Professor Koeber to Japan was the power of Hartmann. Professor Koeber, who did not like to move, replied with an almost immediate rejection at first. "However, Hartmann stood his ground and would not change his opinion by any means". "When I opposed with reasons such as the concern of a long voyage, worries about earthquakes, and that my language ability was insufficient to lecture in English, he just laughed and took no notice of me. In short, he gave me courage and confidence, crushing all of my concerns." His friends also encouraged him. They said it was not long, just for three years. Thus, Professor Koeber finally decided to go to Japan, when he was forty-five years old.

"While I was doing this, I received a letter from Professor Inoue. The letter was polite, written with kind language and invited me to the country of cherry blossoms. I departed Europe on the 30 $0^{\text {th }}$ of April in 1893 and arrived in Japan on the $11^{\text {th }}$ of June." Young Strasser who was the son of a restaurant owner in Munich, accompanied him as a servant. 
At this time, inside the ship he was accompanied by the military physician Dr. Okada. When he arrived in Kōbe, under Okada's guidance they went to a Japanese inn. In later years, when Suzuki Masuo asked Professor Koeber about his impression at this time, he said, "there was nothing in particular, but the pillow was hard and I could not sleep". "What looked strange in Japan at first was the figure of walking wearing geta. I thought about how well they could walk."

Professor Koeber was in Surugadai for a while at first, but moved to the back of the Botanical garden in Koishikawa before long. According to Suzuki, who was writing about Professor Koeber's life from that time, namely from around the age of forty-eight until around fifty-five (Meiji 29-36), Professor Koeber would not leave his books from morning until night. When he woke up in the morning, while waiting for the water to boil, he would enter his study, pick up a book and start reading it. Before long, when the water boils, he would wash his face. After that, he would read the book while drinking coffee. When the time comes, he would go to school by rickshaw - Professor Koeber called transport by rickshaw "the elegant way of running". He did not like to read on the rickshaw, but once he returned, other than the study of piano and meals, he would not put down his book until he went to sleep at night.

He practiced piano for about one hour before or after lunch and dinner. After lunch or before dinner he often had visitors, but he detested that very much and always asked them to "come for a meal". He even invited first time guests for dinner. It seemed to have been a pain to have his study time interrupted. To that extent, he was serious about the study of piano. "This is research similar to the preparation of lectures, not play (spielen)" was Professor Koeber's favourite phrase. He studied very earnestly, especially before concerts. When Suzuki asked if it would be safe not to study like that, as Professor Koeber was very talented, his answer was "no, whether or not an audience knows, I would be bothered if I make a mistake". Professor Koeber's words, "I am striving as much as possible to apply to all of my activities the musically beautiful motto of Roberto Shuman, who said 'always perform with the feeling an expert is listening,", was literally true.

Professor Koeber only performed in front of the public when inevitable, which was mostly for charity concerts. The venues were the youth hall in Kanda, the central hall in Hongō, the music school in Ueno, and so on. Concerts at which he performed gathered a very large audience and were extremely popular. After every piece he received an ovation and the encore was often repeated. I do not know how deeply the audience were able to appreciate Professor Koeber's art, but it is certain that his calm, quiet, refined attitude gave the audience a strong impression.

Professor Koeber's circle of friends was not very wide. However, he warmly welcomed guests. He especially welcomed students with pleasure. Around that time, various people such as Iwamoto, Anesaki, Takayama, Uedatoshi, Togawa and Hatano and Tachibana Itoshige often made an appearance as students. At the meal time, because students did not know the table manners, there were various funny stories.

In this way, Professor Koeber enjoyed having meals with students, but the meals were simple and well regulated. For breakfast, one cup of coffee with a little milk, and a piece of toast. For lunch, soup, boiled beef, vegetables, and three glasses of gin before or after the meal. At times, leftovers from the night before were served. Before the meal, two or three glasses of wine. After the meal, a cigar. The tea was Chinese tea, he did not drink Ceylon tea or Taiwanese tea either. For gin, he was using a glass with a 
thick bottom of one inch, and the mouth less than one inch in diameter that was bequeathed from his grandfather - as the bottom was thick, it never fell just like a selfrighting doll — but after it broke, it was replaced with a small bottomed glass which Suzuki bought in the town of Ogawa. He often drank gin and would add bitter. As for wine, he was using an inferior type from a barrel which the Akaboshi School ordered from France. Tobacco was Habana at first, but changed to Manila later. His habitual cigarette was melachrino, but again, this later changed to French cigarettes. Furthermore, when cold meat was served for lunch, he drank beer instead of wine. He drank Kirin beer, and would sometimes add stout to it. When the lectures of aesthetics and Greek language suddenly increased at school, and when the afternoon periods were created, he brought bentō. Cold meat, boiled egg, ham, bread, and wine in a lemon soda bottle. The amount and kinds were always decided like clockwork. For dinner, gin first, the meal was soup, and two plates of meat and vegetables. After playing the piano after dinner, he would have two glasses of whiskey soda.

Since he was interested in alcohol, other than gin, he stored vodka, schnapps, cognac, bénédictine, peppermint, vermouth, médoc, maraschino, asti (Italian wine), málaga and so on. The whiskey was in a rectangular bottle by Johnston. He drank these occasionally when he had guests, or after dinner.

Professor Koeber was very kind to the cook and waiters who looked after these meals, and also to the rickshaw puller. The separation of rich and poor, and difference in status were of no consequence to Professor Koeber. When he enjoyed playing chess with them as an opponent, he was no different than towards his friends. Also towards their mistakes, Professor Koeber was extremely open-minded. There were times when a rickshaw puller of a long time, who liked alcohol, was drunk even when pulling Professor Koeber's rickshaw. However, if he was drunk, he would surely look down as if to hide his face. Professor Koeber would soon notice it, but always pretended not to know. Once the drunk rickshaw puller even flipped over the rickshaw which had Professor Koeber inside it. However, Professor Koeber continued to let this drunken rickshaw puller pull his rickshaw as ever after that. Because of that, the rickshaw puller later quit this position, but continued to faithfully serve Professor Koeber as a waiter during his time in Tōkyō. Also, one time there was a cook who started a row and raised an edged tool inside the house. As he was too much to handle, it was decided to finally fire him and Professor Koeber made the announcement. People in the house were fearful whether the cook might assault Professor Koeber when he announced the dismissal, but when Professor Koeber gently said "I do not want to let you go, but it is inevitable for the peace of the house", this violent cook started crying and clinging to the table. Professor Koeber's attitude of "not becoming angry" had an effect on the servants to that extent. From his male and female servants, Professor Koeber built a favourable outlook of Japanese people: "I do not know any amiable humans who are better than them, quieter, less demanding, and in no way disrespectful. It is trivial to say that they often deceive foreigners or themselves - and if they do it is usually subtle. The way of doing so is also very naïve. Thus, they rarely try to conceal or make excuses for a deceptive act, so one cannot really get angry at them". However, it is from Professor Koeber's personality which regarded arrogance towards subordinates as "the vulgar base of one's innermost feelings" and that humans' true education and true highmindedness are recognised in the attitude of what is small that led to such an observation. 
This attitude of Professor Koeber appeared not only towards servants, but in his sense of humour towards everyone. Professor Koeber disliked taking a serious attitude to trivial things. In the round trip letters with Max Christlieb (a German gospel church missionary in Tōkyō in those days) and Doctor Ehman, who introduced Professor Koeber to the writings of Carl Hilty, they drew caricatures to tease one another, which extremely amused Professor Koeber. He also enjoyed that Suzuki, who was learning from a sketchbook in school in those days, progressed only one or half a page a day and took a long time to finish, and when he saw him he would ask "Have you finished your 'sketchbook'?" as if it was a pet saying. One morning he hid the sketchbook on purpose which made Suzuki clamour. At that time, Professor Koeber did not forget when Suzuki answered "I can read, but the meaning is difficult" when asked if he understood, and said on the least pretext the joke "the meaning is difficult." Also, during his final illness, while stroking Suzuki's head with his large hand, he said "meaning! meaning!" and smiled. The joke of a warm heart like this is something that all the people who were close to Professor Koeber respectively experienced.

Among animals, he disliked mice. He would not be able to sleep if a mouse entered his bedroom, so at that kind of time, he would open the door and get everyone to poke the back of the bookshelf with sticks to chase it out. However, he liked most other animals. Even snakes, he said "people do not like them, but I do not dislike them, they are a symbol of Pallas Athena. The winding curve is beautiful." He cherished dogs and cats very much. At meal times when a cat climbed onto his shoulder and mimicked beckoning with its forefoot, Professor Koeber would pierce meat on a fork and happily give it to the cat. At one time, Strasser was given a chick and clipped its wings to release it in the garden. It walked on the grass, landed on a tree and pleased Professor Koeber every day. Professor Koeber cherished it and would call "kocho-kocho". In Natsume's writings from he when visited Professor Koeber in later years, it says "this evening I remembered about the chicken and asked how it was, he answered that it died, it froze to death. It had landed on a tree branch in the garden on a cold night, on the next day it had died".

There was a subtle charm in the attitude he took towards humans and animals, which is hard to express with words. This is what both Suzuki and Kubo claim, but, even when we feel dejected for some kind of reason, as soon as we go in front of Professor Koeber, our mind becomes naturally clear. Even when Professor Koeber does not speak to us, just by his attitude, just because he is there, a strong change in our feelings occurs. So it was natural that servants who did not understand the language became emotionally attached to him. He was a man of few words, but more than that he did not need words. At the same time, it became a power to make the other person who is full of themselves reflect. Once the other person starts some kind of argument, Professor Koeber listened to it quietly like he was impressed. He would never refute. And at the end he just makes a witty remark. For example, something like "do you know ignorance is eloquence?" In his final years, Kubo reported a new political incident which he saw in a Japanese newspaper and started some kind of political argument, after listening to it silently, Professor Koeber joked "you are considerably a politician". However, the heart of the other party then returns from the trivial and awkward to the serious problem at hand. This attitude was probably because Professor Koeber thought that nothing good would come from an argument. Emotions are attached to arguments. It becomes an argument just to win. It is considerably difficult to argue purely logically. 
Professor Koeber did not go outside of Tōkyō except to go to Kamakura and Enoshima once. He seemed to have been pleased, saying Enoshima is similar to Niece. Christlieb was once supposed to guide him around Nikkō and Professor Koeber went to Ueno station, but because Christlieb did not come at the appointed time, he took it as an opportunity to return. He was indifferent about sightseeing in Japan to that degree, but he seems to have had many opportunities to come in contact with Japanese music and plays by various invitations at the beginning. Other than that, he was made to see a play at the Russian legation when Danjūrō was called, he went once or twice. Professor Koeber was constantly praising Danjūrō. He noted his good expression, and that the Japanese can be good actors, and so on. Regarding music, other than having been made to listen at music school, he listened at Momiji building on invitation from a Saien temple official. He did not really have any sympathy towards geisha's shamisen or singing, and his opinion was that he rather preferred koto. He also said there was no music in Japan. In later years, in the letter addressed to Sherman, he wrote "I always felt Japanese music to be desolating and boring to death, the formation is irregular, there is no melody or harmony and my unpleasantness increases all the more when it is said to be due to the supremacy of technique". When he was surrounded by geisha in Momiji building, he apparently said "I do not know if it might have been different if they could talk, but I was cramped and troubled because they were sitting on the side silently". However, in his view of Japan in later years, he imagined geisha were "quiet, amiable, bright" and "polite and with no demands" and much more pleasant than Western ladies.

In his Collection of Literary Sketches, Professor Koeber said "Nevertheless I cannot help but regret not having learned Japanese to some extent which could be used in daily conversation. If I was able to speak the language, how much I would have talked together with the people in Shii, namely, people in lower classes by choice. If so, I also would go out to Japanese theatres with pleasure. The Japanese are excellent actors". At the back of this remark, good servants or the impression of Danjūrō like above are probably included. Professor Koeber's Japanese knowledge was just a few words such as tetsugaku (philosophy) and ongaku (music). During his final illness, while suffering from chronic asthma, he pointed to his throat making whistling sounds, and apparently said "ongaku, ongaku".

Regarding his languages, his mother tongue was German, Russian and French were his second languages. Not knowing where he learned both of these languages, he listened to and spoke in those languages from his childhood. What he learned was Latin, Greek, English, and Italian, in that order.

Professor Koeber was extremely ingenuous about money and did not convert his work to money. There was a time in those days when a German teacher was substituted for a lecture, being asked by another colleague for some reason. After it finished, the teacher thrust at a check for the substitute period. That was the usual way as a German. However, when Professor Koeber was asked to act as a professor of classical languages he did so without any special salary. When Suzuki asked "is it not with the exception of the contract?", Professor Koeber said "no, if they use me, I will happily accept it". Also, as for concerts, he accepted a performance if it was a charity event, but he did not accept a reward. And whenever he encountered people who are troubled, especially if a student appeared distressed, he helped by pleasantly giving money. (He never revealed this himself but when people who were close to him noticed and enquired, he did not deny it.) As he did not have any attachment towards money and was extremely 
optimistic, at one point a rickshaw puller made off with his monthly salary. Professor Koeber would usually sign the receipt for his salary, give it to the rickshaw puller and have him deliver it to the accountant. The accountant would then hand over a wooden tag in exchange, and when Professor Koeber returns home taking the wooden tag, Strasser would take it to collect the money. However, on one occasion the rickshaw puller who was supposed to go to the accountant did not return at all. Professor Koeber was not worried and did not go to the accountant to enquire, but because he was bored waiting, he walked home. Strasser who was surprised to hear the story immediately went to the accountant, but the cash had been received by the rickshaw puller a few hours before and already concealed the whereabouts. A German colleague made a fuss at this time, saying he was unable to understand a person who does such a dangerous thing as having a rickshaw puller receive his monthly salary, and that he should contact the police quickly, but Professor Koeber was rather curious why he was making such a fuss. And said calmly “isn't it good that the man who stole it will spend it?" However, because Strasser reported it to the police, the rickshaw puller was caught before long in Yoshihara - Yoshihara where Professor Koeber imagined "one touch pastoral and pleasant elegance". By that time, as Professor Koeber had hoped, the money "had already been completely spent by the man who stole it" and it was not returned.

Strasser often proclaimed he was Professor Koeber's son, probably out of pride. Someone actually spread the rumour that he was Professor Koeber's child born of out of wedlock. When people around Professor Koeber resented and reported to him, he spread both of his hands, shrugged his shoulders a little and said "Na!" and took no notice of them afterwards. It was an attitude of "if that's convenient, that's fine". He probably thought it was pitiful to reveal if Strasser was doing it out of pride. Also, a groundless rumour probably does not trouble someone who is truly confident.

However, Professor Koeber also complained. Suzuki himself appears to have often been scolded. However, the complaints were just momentarily. He did not scold eloquently, but with a gesture like a child who loses its temper, he would suddenly and loudly scold and become bright and clear afterwards. So apparently it was pleasant even when he was scolded. But then the reason why Professor Koeber scolded was not because he was unpleasant or his profit was at risk, but because he was worried about the other person's circumstances. Professor Koeber always said that "humans must have discipline" and was strongly worried about the life of people around him falling into self-indulgence. And the worry would echo sufficiently to the heart of those being scolded.

Every Sunday, he went to Nikolai Church in Surugadai at the beginning, and later changed to the Roman Catholic Church in the town of Sarugaku. However, he was annoyed by the narrow-minded opinion of the priest there and quit before long. However, he spoke much of prayers. He said things like "pray when you go to sleep, just a short silent prayer will do, prayer is the only communication with god".

Regarding his daily life, there was a sense of Professor Koeber's unique affectation. For example, he would put on a hat a little to the side. Or his tie would be curving a little. If someone fixed it, he would put it back. That is to say, that he disliked precise things. Yet he cared only about trousers not getting out of shape. Other than that, even with coats or shoes, he preferred loose comfortable things. Moreover, the nature of liking old things was apparent in his clothing and he wore the same frock coat since he left Germany, which had become a rusty colour produced when black or purple clothes 
fade, and he also wore the same every day clothes for a terribly long time. According to Kubo, in his final years since he resigned from university, he only wore one set of winter clothes. However, even before that he was also wearing old clothes. Until one year before he passed away, for exactly seventeen years, he was wearing the same winter clothes. He very much liked astringent colours from the beginning, mainly black or grey colours. Regarding hair, he was extremely careless and Strasser would sit Professor Koeber in the corridor and cut his hair with scissors without using a comb. He was unconcerned even if the layers were obvious. Later in Surugadai, he had a barber cut his hair, but he would only sit still for about ten minutes and if it took fifteen minutes, he would say that was enough and ask the barber to stop. When he went to Yokohama, Kubo often performed the role of barber, but when Einstein came last year, Professor Koeber heard that he had his wife cut his hair, and was amused saying "that is interesting". (In general Professor Koeber seems to have been very sympathetic towards the attitude of Einstein and his way of life.) Furthermore, regarding his beard, it was in an extremely fussy order. Cut left and right and back in a sharpened triangle.

Professor Koeber, who disliked new things did not even change his family doctor when possible. At first Bälz, later Miura. However, he would not see the doctor easily. In regard to his father being a doctor, he often associated with doctors during his time in Germany so he understood pathology, the name of diseases and medicines and mostly cured things by himself.

Similarly, because he was not interested in new things, he almost never paid attention to newspapers and magazines. He took English language newspapers in Yokohama at the beginning, but he would only look for two or three minutes and just roughly scan foreign telegrams. When asked why he is getting newspapers although he was not that interested, he answered half-jokingly "because I need paper". It was the same in his final years, and Kubo seems to have often said to Professor Koeber "until when are you looking at the newspaper?" Even so, Professor Koeber was able to easily find what he was interested in, for example on literature, during the two or three minutes.

He did not go for walks, but enjoyed going shopping in Ginza by rickshaw before dinner on a fine day. However, he decided to shop in Kameya and purchased groceries, tobacco, and confectionary for the people in the house.

When the Russo-Japanese War had started, it had been about one year since he moved to Surugadai and most of the other Russians had returned to their country, but Professor Koeber did not try to go home and the Japanese did not make it a problem. Professor Koeber disliked political issues and was also cool about the war, and apparently said he had no emotion towards Russia and that he would rather be here.

Regarding the kind of influence Professor Koeber had upon his pupils in the above mentioned era, it seems that the words of Dr. Nishida Kitarō, who only audited Professor Koeber's lessons for the first year, while simple have many implications. That is, the phrase "when Professor Koeber came to our country, I think he disliked our country's frivolous and thoughtless academic tradition”. Dr. Nishida says as an example that he was directly warned that it was thoughtless to try to understand Western philosophy without knowing classical language, and also this warning was similarly repeated in our time, twenty years after, but the problem was not only about classical language. The attitude of total adoption of European culture was the problem. Without trying to move the root, just trying to pick up the flowers in order to surprise the public. 
The result is that the person who carries the flowers becomes greatly respected, but the plant from which the flower blooms does not grow in our country. In such a climate, scholars and bright people in those days were ostensibly showing off their knowledge of Europe, and with bold gestures. Such pretention probably felt absolutely intolerable to Professor Koeber. Among the previously mentioned students in the early days, Takayama Chogyū and so on were the representative of such a tendency. That is why Professor Koeber extremely disliked Chogyū.

Therefore, Professor Koeber modestly and quietly strived to throw away the flowers and move the roots to Japan, where Chogyū was praised extravagantly as if he was a great thinker. The sense towards the "genuine article" was generated little by little surrounding Professor Koeber. We can say that this influence had much greater significance than Professor Koeber's status and achievements in academia. An extreme example of such an influence can be seen in Professor Iwamoto Tadashi. The attitude of radically eliminating any light-handed method, rather paralysed him, and blocked the path that enables the development of freedom. If that is the case, this standpoint of paralysis would take a dreadfully intolerant attitude towards others. Looking from Professor Koeber's open-minded approach, which could see the eyes of sympathy however lost one was, the attitude of Professor Iwamoto would have seemed really narrow. In later years, Professor Koeber said "Iwamoto is strange" which seems to suggest such a point.

I think that the cases of both Dr. Hatano Seiichi and Dr. Fukada Yasukazu, and the piano apprentice Tachibana Itoshige should be taken as examples of Professor Koeber's influence appearing straight without bias.

The strength of influence Dr. Hatano received from Professor Koeber appears in his Recollection. At first, the doctor possessed innocent and plain feelings of deep emotion towards Professor Koeber as a student. Professor Koeber's lectures were not showy as to attract people at all, but the doctor developed a "craving for what was high and pure" and which was aroused and fulfilled by Professor Koeber. Professor Koeber keenly conveyed a Greek-style love of wisdom to the heart of the doctor. Then, the doctor strived to set foot on the correct path of philosophy, as Professor Koeber ordered, and enter into philosophy. He also started studying Greek language after being initiated by Professor Koeber. So the doctor says "for myself, Professor Koeber was the master who truly led me to philosophy".

However, as people directly came into contact with him, a much bigger influence was derived from Professor Koeber's personality. A person who has a mature personality like Professor Koeber is certainly rare. It does not just come down to being virtuous and gentle. Professor Koeber was extremely strict towards himself and his sense of responsibility was also very strong. Not many people prepared their lectures as faithfully as Professor Koeber. However, he did not appear strict at all, but was truly bright and peaceful. As the doctor expresses, "for Professor Koeber, life itself was art". In this point we can say that Professor Koeber abundantly personified the tradition of Germany, but to go one step further, the foundation of Professor Koeber's art of life is rather that of the Greek philosophers. "Professor Koeber's objective of conduct was a mix of the refined enjoyment of Epicurus with the graveness and seriousness of the Stoics, add respect of liberal arts to other various schools and decorate all the good and beautiful things which characterised the classical era with frank devotion." Professor Koeber often said he was Epicurean and pointed out that the life of Epicurus' ideal wise 
man was modest, simple, calm, free and isolated from the noise of public life. Professor Koeber's free personality, like this, gave the doctor the idea of Greek philosophy through his actions.

However, the influence did not stop there. Professor Koeber saved what gives depth and softness to Greek freedom from self-respect, arrogance and coolness, which it was prone to, and with unearthly brightness he purified what was controlling. That is, the ideal of limitless love, and the grave and modest attitude towards that which is completely holy, namely, Christian belief. Originally, Professor Koeber did not place importance on dogma or rituals. He did not really go to Church either. This attitude was consistent and even before his death, he refused to be anointed at the end, and willed not to use Church rituals for his funeral. However, his Christian belief was truly firm. The doctor was strongly struck by the totality of Professor Koeber's personal Greekstyle freedom and Christian devotion. So while the doctor listened to a joke from Professor Koeber, saying he was more pagan than Christian (mehr Heide als Christ), he recognised the example of Christian devotion which was connected to true spiritual freedom in Professor Koeber.

In comparison to the case of Dr. Hatano, the account of Dr. Fukada seems to emphasise the component of personal passion. Dr. Fukada entered the university in Meiji 32 [1899], three years after Dr. Hatano, and before long he started to regularly visit Professor Koeber's house in Koishikawa Hakusan Gotenchō. Dr. Fukada was a handsome and charming young man, and on top of that he excelled in languages and was blessed with sensitivity and strong understanding. Such a unique young man approached learning with pure emotion and devotion, and as such it is natural that Professor Koeber loved this adorable young man from the bottom of his heart. At least once a week, this young man made an appearance in the dim study full of books, scattered with the smell of tobacco, secluded in only one western building at the back of the botanical garden. The love and understanding towards Greek and German literature progressed remarkably as Professor Koeber led. In this way, three years passed, and when Fukada graduated from university, Professor Koeber made an appearance at the farewell party for the graduates for the first time, showing how much Professor Koeber loved this apprentice. At the same time that night, this young man who walked Professor Koeber home from Hongō to Koishigawa under the faint moonlight had a cup of sake again in the study and drank himself unconscious, thus showing how frank his devotion had become.

In the summer, when Professor Koeber moved to the house along the canal in Surugadai, Fukada spent his daily life in the Japanese room on the second floor there. And for the full five years after that he came in contact with Professor Koeber in the morning and evening. It continued until the morning of the day when Fukada departed for Europe as an exchange student of the Ministry of Education in the autumn of Meiji 40 (1907). It is needless to say that as with a solid friendship of this kind, of a close teacher and student relationship, they were indispensable to one another. However, according to the recollection Fukada wrote after Professor Koeber passed away, Fukada had a strong feeling of regret from not having sufficiently served Professor Koeber: "Instead of looking after Professor Koeber and behaving appropriately even only to the word Professor Koeber called me 'friend', I did nothing but receive Professor Koeber's favour for a long time. And the sin of making Professor Koeber sad is not insignificant." This grief is based on Fukada's over-sensitive disposition, but it also shows how deep Professor Koeber's expectation of his apprentice was. 
Fukada says "I moved away from Professor Koeber by my engagement and independence". The engagement shows that Fukada's sentiment was not only occupied by Professor Koeber, and the independence also doubtlessly separated Fukada from Professor Koeber in the form of studying abroad in Germany for three years and his appointment at Kyōto University after he returned, but Fukada's unique point of emotion can be seen where he writes as if it was inexcusable towards Professor Koeber. Professor Koeber always said to Fukada "you will go away from me but I will never leave you". Quite so, Fukada sometimes tried to separate himself from Professor Koeber, but he did not leave Fukada. Professor Koeber's fraternity was deep to that extent. To think about it, Fukada's heart ached. The last incident that Fukada talks about in his Recollection sadly shows the intuitive traffic of heart between this teacher and student. About two weeks before Professor Koeber passed away, Fukada proceeded towards Yokohama from Kyōto to inquire after him; he made Professor Koeber's 'Hoffman Theory', which was published in Thought, the topic of conversation and stated his approval towards it. Thereupon, Professor Koeber asked "do you not think Eihendorf's criticism of Hoffman is thoroughly unpleasant?" Unfortunately Fukada had not read that part. Upon confession, he felt greatly pained. Writing about the feeling at that time, Fukada notes "at that moment I felt like proving that I belong to Professor Koeber by expressing my knowledge about all the pages of Professor Koeber's book". To the confession, Professor Koeber grieved "it is regrettable, but you are not my reader. I am writing for you, but my readers are probably only the translator and myself'. This remark cut to the bottom of Fukada's heart. So Fukada experienced deep remorse after Professor Koeber passed away: "I have lived exactly half of my life with Professor Koeber. I always existed only in him. If possible, I wish I had said this to Professor Koeber when he was going to eternal sleep." At this time, Fukada was forty-six years old.

In comparison to Fukada's case, Tachibana Itoshige's account seems much happier. Tachibana's personality, which was simple, modest, sensitive and delicate, fits Professor Koeber's preference. Tachibana was a student when Professor Koeber went to teach in the music school in Ueno for the first time and at the first period, he was unable to get the right tempo or finger placement due to embarrassment; Professor Koeber apparently laughed and said "you cannot practice if you are afraid like that". Before long, he went to the house in Hakusan and received training and even after he moved to Surugadai, they were in constant contact. He was one of the people who sat at the dining table on the last night when Professor Koeber was planning to leave Tōkyō. At that night, Professor Koeber apparently said "let us say Auf Wiedersehen! lively as always and part". Tachibana writes that he was able to see him again in Yokohama, but it was "precious nostalgic months and years for us". He received an imperial appointment as a senior professor at a music school, and was teased by Professor Koeber who called him "your Excellency" (Euer Exzellenz) which was also probably at this time. After Professor Koeber's death, it seems that it was probably Tachibana who most often visited the cemetery in Zōshigaya to clean the grave and bring fresh flowers.

The above three favourite pupils represent the first half of Professor Koeber's Japanese stay, though Uozumi Kageo and Kubo Masaru are the ones who represent the latter half.

Right after the Russo-Japanese War, from when Fukada was still in Professor Koeber's house, Ishihara and Abe started to get close to him and then Fujiwara, 
Uozumi, Abe, Miyamoto, Koyama, Itō, and Yamaguchi started to actively visit Professor Koeber. Uozumi was passionately devoted to Professor Koeber from around early summer of Meiji 40 [1907] and also came to be closest to him.

From before Uozumi visited him, he regarded "it is an honour to get a glimpse of Professor Koeber" and felt like even "to think about the holy figure of Professor Koeber, I feel is awe-inspiring". When Uozumi heard Professor Koeber's words "I like Uozumi, so bring him" from Abe, he felt "flushed, embarrassed and happy". When he was finally invited to dinner, he even "cried on countless occasions out of gratitude". At that time, Koyama apparently said "it must be you who comforts Professor Koeber, who is already sixty and lonely in his final years without a wife or child. Not only are you loved by Professor Koeber, but even when you were in middle school you had already loved and respected him, so it is even better". His first visit was with Ishihara and Abe, and they joked from the beginning to the end, but once he approached him, "his personality like jade with which to be intimate and adore" increasingly excited Uozumi (Setsuro's Posthumous Manuscript p.626). After that, he started to visit Professor Koeber frequently. While he had not met him he thought of him as a god, and after he started to receive his teaching Uozumi adored him like a father, and once he started going in and out of Professor Koeber's house, he ended up being treated like his child. Uozumi wrote about that time, "I feel obliged as he cherishes me excessively." "I do not think it could possibly come true in Professor Koeber's high estimation, but I have resolved myself to research his personality from the foundation and to receive as much influence as possible". In this way, in the following winter, when Professor Koeber suffered from pneumonia, Uozumi stayed the whole time to nurse him day and night. At the end of autumn, after about one year and a half since the first visit, he wrote "Professor Koeber is always emancipation for me. - I am going to see his mask. I stand in front of Professor Koeber and look the thinnest myself. I feel most free and peaceful. - his personality recognises the Greek direction in Christianity well, and also the Christian direction of Greek thought. In short, personality. Enviable personality. In front of Professor Koeber, I always feel knowledge and things that do not need explanation. I feel more and more that Professor Koeber's affinity is great. There is no complaint in front of him".

The devotion of Uozumi was naturally relayed to Uozumi's various friends. Not only that, we, who were in senior high school at that time, also felt a spiritual connection with Professor Koeber as we got to know his personality and words through Uozumi. There was a general tendency among our peers, who were around twenty years old at that time, to make our heart's work about the significant value of life, and at times we sought religion to ostentatiously show our heart, but one day it was conveyed that Professor Koeber said "such a tendency is pedantic". We cannot say that we sufficiently understood the meaning at that time. However, we were astonished and at a loss and could not but reflect. To that extent, Professor Koeber's words started to already have an influence upon us.

I received Uozumi's instruction from before I started high school, and received a strong influence in various regards after that as well. When Uozumi listened to the lecture on the history of Japanese art at university and spoke with intrigue, I borrowed the notebook to read it and went to Nara in the summer break. Uozumi became absorbed in Shōnosuke, and I became infected and started enthusiastically going to the entertainment hall, and as a result I learnt an important point in German language. 
Since it was like that, Uozumi's devotion towards Professor Koeber soon infected us. He said to us, "when you enter university, I will take you to Professor Koeber's place", which was Uozumi's way of comforting us. Kubo Masaru, who had only just become a naval lieutenant, but wanted to quit the navy and enter the philosophy department right around that time, came into contact with Uozumi while studying German language for entering prep school, and similarly started to be infected with devotion towards Professor Koeber.

I entered university in September of Meiji 42 [1909] with Kubo. And welcomed Professor Koeber with the feeling which was prepared by Uozumi from the beginning. The smiling, pure face of Professor Koeber, who came walking slowly and quietly along the corridor seemed almost holy. However, once he started the lecture, the kind face collapsed and he seemed to become a terribly old man. To that extent, lectures required effort. I tried not to neglect Professor Koeber's lectures and would make special preparations, like sitting in the front row and was nervous trying not to fail to hear even one word. This attitude only lasted for about one year, but during that time I was actually able to study with the feeling of obedience. Also, Professor Koeber's lectures were easy to understand, so being able to understand was pleasant for myself. Then, soon after I started going to the lectures, when Uozumi conveyed Professor Koeber's words "that young man has sympathy for my lectures", I could not help but be delighted from the bottom of my heart that my feeling was understood by him.

In this way, in October of that year, I visited Professor Koeber's house with Kubo, taken by Uozumi, and was treated to dinner by Professor Koeber for the first time. It was not deeply significant for me, but it became a largely memorable day for Kubo who came into close contact with Professor Koeber for the first time, as he would later become an important companion in the latter half of Professor Koeber's life in Japan. On that evening, I experienced the tastes of vodka and stout for the first time in my whole life. Professor Koeber constantly recommended it, saying it was nothing special, so I brought it fearfully to my mouth, then he said "that is not the way, this is the way", and showed me by downing it in one go. Mimicking it, I drank the schnapps, then it was like there was an explosion inside my mouth and I could not help but dart my eyes about. Seeing that, Professor Koeber laughed pleasantly. I learned the way of drinking stout similarly. Because of that memory, when I look at vodka or stout, even now, I cannot help but remember Professor Koeber. Other than that, rolled cabbage was very delicious, and as Professor Koeber recommended, I took heaps for my second plate. I felt terribly jealous that on this night Uozumi was without hesitation and could tell jokes to Professor Koeber.

My classmates, Kuki and Iwashita started to frequently visit Professor Koeber after that, but Kubo especially came to be loved by Professor Koeber because of his simple and compassionate nature. Here, Kubo's devoted service that adorned Professor Koeber's final years began. Towards Kubo's faithful way of service, Fukada gave an utterance of admiration and envy afterwards. I think it was the New Year of Meiji 44 [1911], about one month after Uozumi had passed away from typhus, when Kubo lived in a little western room at the entrance side of Professor Koeber's house. After that, Kubo did not leave Professor Koeber's side until the end.

Before very long, one accident happened in Professor Koeber's house. It was the suicide of his servant, Strasser. This accident seemed to have been a great shock to Professor Koeber. However, he felt great pity for this person who committed suicide. A 
part of Strasser's ashes were buried in Aoyama cemetery and another part was preserved carefully so Professor Koeber could bury them in Munich, the hometown of the deceased, when Professor Koeber returned to his country someday. And when the will was recognised in February of this year (Taishō 12), Professor Koeber had treated Strasser very seriously. Saying, he would like Strasser's ashes to be buried in Munich when Kubo goes to Europe someday. However, it is alright to put them in the cemetery in Tōkyō. He wanted Strasser's grave to be protected and treated with respect. And wanted his gold ring returned to Strasser's mother as a memento (or if she had already passed away, to his siblings). - Not only that, we discover the following passage in the Sequel Collection of Literary Sketches: "Also on the looks of people who passed away willingly, the same peace, and same holy brightness was recognised. Moreover they are said to have commited a 'sin' and to be rejected by God. This claim should be rejected by God. The reason is because it includes doubt, no, denial, towards God's justice and grace." Those who know that they are not suitable for this world and are of no use, and that their existence only adds burden and trouble to others, commit suicide trying to go to the other world "I wonder is this rather the only logical death for useless humans, - and a high minded heroic action."

Around the time when Professor Natsume visited Professor Koeber, with Abe in the summer of 44 [1911], about which Professor Natsume himself wrote lively descriptions of "an old smouldering house" on the cliff top of Kōbusen, "ascending the high ladders on bare feet in dim light making a wobbling noise", "smashed colour" in the study room, the figure of Professor Koeber, "who looks eternally fresh and youthful" "without putting on a collar or necktie, or to throw on one yellowish coloured thin business suit or a stripped patterned cotton crepe shirt", and conversation around the dining table while listening attentively to the sound of clear-toned cicada crying near the window in the evening exist there (Sōseki's Complete Works Vol.9 p.407). In his text, Professor Natsume displayed warm respect towards Professor Koeber's "disdain for fickleness", indifference to trend, and "extremely calm" personality and life. Professor Koeber apparently frequently praised Professor Natsume to Kubo after this visit.

Professor Koeber decided to leave Japan with Kubo on the ship departing from Yokohama on the 12th of August in Taishō 3 [1914]. In the Asahi newspaper on that day, Professor Natsume wrote "farewell to Professor Koeber". Before that, on the night of the 15th of July, Professor Natsume, who received an invitation for dinner notes "when I tried to leave Professor Koeber's house to return home, I was asked to write in Asahi newspaper because he wanted to leave a simple phrase to his friends and especially students who received his guidance: goodbye, farewell. Professor Koeber did not want to say anything other than that." Then, with Professor Koeber's permission, Professor Natsume announced the above remark of farewell in his own words adding Professor Koeber "seems to leave Japan secretly", Professor Koeber only cherishes "love and feeling which connect person to person" transcending place, time and money and so on.

However, on this day, Professor Koeber did not board the ship. The First World War, which was started by the German declaration of war towards France on the 3rd of August, and the British declaration on the 4th, kept Professor Koeber in Japan. That all happened in an instant. So, although he was only supposed to stay for a week while he waited for the ship, Professor Koeber ended up spending a full nine years in a room with a balcony attached, facing the garden on the upper floor of the Russian consulate. 
Regarding Professor Koeber's daily life in Yokohama, there is a detailed description composed by himself (Sequel Collection of Literary Sketches p.468). Morning: While taking breakfast of coffee and toast, I read the bible or Hilty. After the meal, I start the work of writing. Afternoon: Short nap. After that, reading. Take a walk on the coast for a while on a fine day. Kubo comes around 5 pm. Hear about current affairs which appeared in Japanese newspapers, while drinking tea. Then we get on with writing work or reading research. After $9 \mathrm{pm}$, I read something light and go to sleep. - This life was repeated daily and well regulated.

Professor Koeber notes "I had the desire to start a long, large work while my emotional strength is still quite fresh". One was to revise English lectures and rewrite them in German. Another was to write "what is overlooked and forgotten in literature and philosophy". However, the inconvenience of having no quiet room to work in and not being able to conveniently assemble a collection of books prevented Professor Koeber from this task. Moreover, Professor Koeber did not like to alter a borrowed room to remodel it to a study.

Thus, Professor Koeber was satisfied with writing collections of literary sketches, reading, the realisation that he had devoted himself to the next generation, and said, "At the end of my pilgrimage in this world, one becomes a true friend and a loyal, life-long companion 'until the dark house is reached'," satisfied with having Kubo as a younger traveling companion, he praised old age, did not get angry or sad even about being prevented from going back to his country and spent his final years quietly.

About two and a half years ago, Professor Koeber suffered from pneumonia and could not go down the stairs for a while. After he recovered, he went down the stairs once or twice, but because it was a little painful and also because it was troublesome to go out to the dining room, he decided to take his meals on the second floor. Walking was just strolling on the balcony. From the pneumonia, moisture came to his feet. Kubo discovered it and told the doctor, but the doctor did not really make it a problem and Professor Koeber did not worry, so Kubo teased Professor Koeber by calling him Oedipus (Foot blister). ${ }^{6}$ The doctor seemed to have already noticed his heart was weak and that he had light arteriosclerosis.

Around October of last year (Taishō 11), Professor Koeber suddenly started saying he was unable to see. At that time, Kubo received the feeling that senility finally came and worried that he might not be able to work anymore. He bought glasses, but they did not fit well. The ophthalmologist said it came from his kidney, though his family doctor said there was nothing wrong with his kidney. After this, he needed a magnifying glass to see things and it took a terribly long time to look through books and other things, so his work did not make any progress.

Around the 5th of April of this year (Taishō 12), his heart ached terribly at dawn and he called for the doctor. After that, every two or three days, the pain repeated two or three times. So the doctor would visit once or twice a week.

Around $3 \mathrm{pm}$ on the 25th of May, an intense spasm suddenly occurred again. Without knowing that, Kubo visited around 4 pm, Professor Koeber was in a cold sweat and suffering from intense pain. Because the doctor's visit was delayed the pain

\footnotetext{
${ }^{6}$ The Greek word Oidipous literally means "swollen foot". In Sophocles' tragedy, Oedipus Rex, the protagonist is given his name as an infant on account to his injured and swollen ankles.
} 
continued longer. On that day, or the following day, Professor Koeber said to Kubo "I will die this time". To a Swiss doctor, he also said "I would like you to tell me if I am going to die". He also said "I have often suffered from illness but this is the first time to suffer like this". However, once he picked up, he also felt he could survive for about a year. In the final few days he had clear presentiments. He often said he was going to die this time. At the first doctor's visit of Manabe, he said "ask what that doctor says, how long I will live".

On around the 27th of May, he stood on the bed and told Kubo his will. People whom he wishes to convey a message to, people to visit when he goes to Germany, and about the funeral, - on the will in February, he wrote no church-like or public pomp (prunk), but he did not write anything about whether to call a priest. However, in the verbal will at this time Professor Koeber clearly ordered not to call a priest and said "you become a priest and read a beautiful phrase from the bible, there might be people saying various things but refuse them firmly", - saying these last requests, Professor Koeber advised "write it down so as not to forget".

However, Professor Koeber still had strong stamina. When he got up, he did so with surprising power. Kubo thought he was still alright.

In June, his laboured breathing gradually became severe due to asthma. Also, other than the heart pain from the spasm, pain occurred all over his body: "Saliva comes out and I am suffering, I wonder if it is because of the medicine", he said. From around the 7th of June it was the most terrible.

On one morning, Professor Koeber suddenly asked Kubo "what is the biggest achievement of Queen Victoria?" Kubo thought it strange and had an odd expression on his face which caused Professor Koeber to say "well, I have not normally thought about such a thing, but I was thinking about that in my dream all night last night". It seemed that his childhood was returning to his mind.

On the night of the 12th, he was lively and told jokes. Until then, his complexion had not changed from normal at all, but on the 13th it started to become bluish-purple. His state was of a high fever and laboured breathing. Because of the intense pain, he shouted loudly "I will die! I will die!" (Sterben! Sterben!). From the evening, the feeling might have weakened, as he did not announce any pain. And at 4.30 am on the 14 th his heart stopped.

It was in the afternoon of the 8th when I saw him for the last time. Professor Koeber sat up in bed and bent his chest to breathe painfully, but nevertheless he welcomed me with a smile filled with a warm heart, not like a seriously sick person. Professor Koeber's hand was big enough to wrap around my hand and he did not look slim at all. When I could not make out what Professor Koeber said, Kubo interpreted it as "I will call everyone $d u$ (you) from now". Professor Koeber said "that is more human, more delightful..." (Das ist menschicher, liberlicher...). He held a handkerchief in his left hand and was constantly wiping his mouth. His body looked to be in pain, helpless, and unable to do anything, but his quiet, warm-hearted smile still remained. Kubo said a joke, such as Watsuji was a person who only smokes on Sundays (Sonntagstaucher). Feeling the pain, although there were many things I very much would like to say, but could not put into words, I watched over Professor Koeber's face. Professor Koeber said "Be careful of vice. Awake and alert! (Hüte dich vor Bösen! Wach und munter!). Kubo repeated that as well. I drank wine with Professor Koeber, feeling like I was given a motto to live by. 
The last time I saw Professor Koeber's gentle, smiling face was when I was leaving the room.

\section{References}

Chamberlain, B. H. (2007). Things Japanese. Berkley: Stone Bridge.

Koeber, R.M.K. ed. (1998). Nine songs. Ongakunotomosha.

Kubo, M. (1923) 'Biography of Dr Koeber'. (Kēberu Hakase Ryakuden ケベル士略傳) in Shiso: Special Edition in Memory of Professor Koeber (august), 1-5.

Löwith, K. (1998). Martin Heidegger and European nihilism. New York: Columbia University Press.

Marcus, M. (2009). Reflections in a glass door: Memory and melancholy in the personal writings of Natsume Soseki. Mānoa: University of Hawaii Press.

Natsume, S. (1994). 'Koeber sensei’ (Kēberu Senseiケ ベル 生) in Soseki Zenshu (Vol. 12, pp. 461-466). Tokyo: Iwanami Shoten.

Nara, H. (2018). An adorning gaze: The idea of Greece in modern Japan. In Receptions of Greek and Roman Antiquity in East Asia edited by Almut-Barbara Renger and Xin fan (pp. 175-201). New York: Brill.

Nishida, K. (1923). 'Remembrance of Koeber sensei’ (Kēberu Sensei no Tsuikai ケ ベル 生の追懷) in Shiso: Special Edition in Memory of Professor Koeber (august), 32-33.

Piovesana, G. (2013). Recent Japanese Philosophical Thought 1862-1996: A Survey. New York: Routledge.

Uozumi, K. (1914). Setsuro's posthumous manuscripts (Setsuro Ikō 葐遺稿) edited by Abe Yoshinari. Tokyo: Iwanami Shoten.

Tachibana, I. (1923). 'Memories' (Omoide 想ひ出) in Shiso: Special Edition in Memory of Professor Koeber (august), 17-24.

Watsuji, T. (1962). Together with Watsuji Tetsurō (Watsuji Tetsurō Tomo ni 和辻哲郎共に). Tokyo: Iwanami Shoten.

Watsuji, Tetsurō. (1992). Attempt at an Autobiography (Jijoden no Kokoromi 自叙伝の試み) in Watsuji Tetsurō Zenshū Vol. 18, Abe Yoshishigo et al., (pp. ) Tokyo: Iwanami Shoten.

Yuasa, Y. (1996). 'Appendix: Correspondence with Yuasa Yasuo' in Watsuji Tetsuro's Rinrigaku: Ethics in Japan (pp. 311-324). Translated by Yamamoto Seisaku and Robert Carter. New York: SUNY Press. 